American Research Journal of Humanities and Social Science

(ARJHSS)

ISSN (Online) : 2378-7031

Volume 2016, 5 pages

AMERICAN RESEARCH JOURNALS

An Academic Publishing Fouse

DOI: 10.21694/2378-7031.16001

\title{
Costume Design in Albanian Theatre in Kosovo
}

\author{
Agnesa Muharremi \\ Faculty of Arts, University of Prishtina, Kosovo \\ agnesa1muharremi@hotmail.com
}

\begin{abstract}
I treated costume design for Albanian Theatre in Kosovo; in this text .This were active component although, in fact in Kosovo Province Theatre named Albanian National Theatre in Pristina, Kosovo, costume designers were educated in Belgrade, Serbija. Sometimes the costume design was connected with concept and component -stage design, but in more cases from History of Art could be seen that costume design act as independent art. In the very beginning of created the costumes for actors in drama and comedy were presented many elements such as : Modeling, cutting of illustrative characters, especially the position of people high(rich) class, places, province, ages, occupation, gender and climatic conditions.
\end{abstract}

Keywords: Costume designer: is a person who designs costume for a film, theatre, stage production or television. Costume designer create the look of each character by designing clothes and accessories the actors will wear in performance.

Costume design: is the envisioning of clothing and the overall appearance of a character or performer. Costumes may be for a theatre, cinema or musical performance and also refer to the style of dress particular to a nation, a class or a period.

Stage design: is the art of the creating the visual image.Also is known as a stenography or set design and is the creation of theatrical, as well as film or television scenery.

Modeling: a profession of a person who models, to create a representation of something.Cutting form of clothes: the cut of clothes refers to way tha garment hangs on the body based.The shape and style in which a thing is cut or formed or made.

\section{INTRODUCTION}

First of all ,clothes are natural fact, understanding as a human need to protect their body by atmospheric climate factors, mainly from the cold ,frost, winter , precipitation and also from high temperatures ,burning caused by solar radiation,etc. Well clothes appeared as a vital necessity and existential relation of the human being with nature, place, physical environment and time when people are living. Except natural needs, physical and existential, dressing change with social and historical development of the people alreadygathered in large social groups (tribe,ethnicity, population, nation,race) and in some other features, that were distinctive and characteristic of certain social community.

Mostly they became gradually isolated signs of an ethnic community located in urban enviroments, subject to certian conditions interoperability to interdependence from one to another, also distinguishing the community as a whole.

About coating we can say that it apeears like an entomological and ethnographic fact. Clothes of different consideration and the beautiful form, harmony of elements and dimensions,proportions and colours, the power of visual expressiveness and so on. 
Thematic diversity, motives and ornamental by environment, where social ethnological community was located and living, it was said in specific gender ( male-female), in generations (old-young), the hierarchy socioeconomic, elite-people or leadership-workers.Authentically of costumography as an art is an easthetic art;and beautification.In this case enter additional factors such as : selection of clothes or skinclothes for coating, way of cutting and sewing to create it, colours and used decoration, material, harmony, symmetry ,selection...In this case suposed that consciousness of costume designer now as an easthetic consciousness, which is different, relish, estimates and reproduce -the beauty.

For sure the concept "Coating" with concept "Costume design " aren't the same even though they often has the similar meaning and in some way they create easthetic misunderstanding in values, especially in function that they have.Human society from coating to costume design passed in many other internal developments that spread over thousands of years .Clothing also has several functions such as : utility, pragmatic functions,. Except this costume earn especially easthetic and ornamental values by decorating, manufactured cloth in overlap and a lot of ornaments.Costume design looks different, colours have not simple visual appearance but more painterly from their realizing with this or other elements; The composition ,cutting and sewing ways , embroider , decor spreading, decoration elements , volume,architecture and so on..Overcoming from coating to costume design is an overcoming qualitative, which shows the degree of civilization, overcoming by barbarism to citizenship. ${ }^{2}$

Costume design in Albanian Theatre in Kosovo have been an active components and this because of the fact that District Theatre in Kosovo as named National Theatre in Pristina and had many costume designer who were educated in Belgrade,Serbia. Sometimes the costumography get involved in scenography concept and realized from painter-stage designer, but in most cases from History of Theatre is said that this component -costume design in Kosovo has functioned as a special, appreciated and substantive art in theatre plays.

Beginning the use of clothing in drama and comedian characters were used with modelings, cuttings with ilustrative characters , include class position of property, places, people, province, genders, climatic climes,etc,.. in some drama plays which were coming from foreign authors, were used creating ethnographic details to present some costumes from different people, include their character which they offered to us. In the late 60s we have noticed a movement to modern elements and costume begin to be released from national ethnographic elements and becomes more modern in some form of elements cutting, always by the idea of the costume designer and director for theatre play, include literary drama and actors play.

" Costume design for theatre generally has expressed social and emotive position of characters ,also give artistic and hystorical information for them"3

The National Theatre in Prizren immediately after the Second World War, and later when this theatre moved to Pristina in 1949 is well known as a Theatre of Provinces Folk of Kosovo . In the beginning years in albanian drama, in costume design were used some folk Albanian elements with Albanian subjects.Peasant dress were used widely , folkdresses : "tirq", "xhamadan", "fustanella", "xhubleta”, " qeleshe", "kilota" and some other folk typified clothing accesories .

One period of ethnographic costume used old torn clothes (especially poor layers) and new fashion clothes, clothes for office , celebrations and ceremonial ( especially high layers or "feudal-bourgeoisie"). 
Albanian critical Art and professor -Josif Papagjoni about Albanian Theatre says "costume to character, costume to coating, costume to decor were simple problem to solve, often it was misunderstood. Costume-coating and costume-decor have expressed some formal aspect colours in performances .By changing different ambients, it could be created unity of volumes and colours between them. Through scenography and directorial concepts ,costume design in this case expressed conceptual certain aspects eventhough esentially in some special cases costume-coating and costume- decor were more formal,colourful and volumetric ${ }^{4}$.This observation is similar to costume design situation in Albanian Theatre in Kosovo. Exact costume-character,costume-coating, costume-decor reflects content ( costume-character), as well as in colour and formal ( costume-coating), physical and enviroment ( costume-decor).

Under the influence of developments in the European Theatre and beyond this is especially after Second World War,clothing accesories suffered reconception in the ornamental and decoration way, pace,coloristic, silhouette,way of cutting especially introduction of meaning that corresponded with symbolic language from director ideas, plays , movement from morphology and artistic expression of costume which is conceived now beyond the descriptive,pragmatic and utilitarian aspects.

A theatre play from author Ismail Kadare with his known novel "General of the Dead Army", was played in 1972 in National Theatre in Pristina. Costume design and play were realist, where in scene wedding were ethnographic costumes with some symbol elements which show to us a metaphor about thought as a universal thought. For example, -Albanian critical and professor Josif Papagjoni says : Old women with black clothes in the middle of the stage with Nicen as a corbie ,swearing and ominous for general and priest create a tragic ambience which is respecting of others as a white clothes of bride expressing happiness and continuing life, living with them complementing each other in costume-coating and costume-décor way. ${ }^{2}$

According to easthetes sometimes costume design in theatre in Kosovo turn over in "Fashion" when artistic information came from text or character suggested something else while costume was taking another directions and in this case this costume design was created simple just to "respect" a dominant theatre society Costumes, symbolism and allegory of clothes haven't been always shown as a style and an artistic paradigm of theatrical costumes. Sometimes before 70s it looks like criticizing from emancipated opinion calling "Silly games to fantasy", form play for form, lack of social purpose or decadency ,etc,.

Costume design in Albanian Theatre in Kosovo has a main problem to create this way of meaning : Costume character. Until 80s this way of meaning was dominated and had negative impacts in theatre and costume design from presence of known principles of realism which although was more tolerant than in Albania .

In most cases this meaning of costume shows descriptive external element, utilitarian appearance as a visual sign to distinguish affiliation class, wealthiest, economic or national, regional sometimes professional, etc,. In some plays costume design was estimated for special way of modeling.

Describing Historical-social aspect arrived some ethnographic and civil models to create artistic figures on costume. This mean also other theatre component such as stage design and both they show to audience surreal and phantasmagoric imagination.

In play "General of the Dead Army" novel from author Ismail Kadare, realized in 1972 from known director Pirro Mani which costume design of dancers presented the dead raised from graves and dancing around with black clothes and white ribbons. This game of actors with beautiful costumes reminded us in the bones of the 
dead : cut and sewn clothes with thin pieces were attached to the body with uncovered arms while actors with carrying crosses excerpt expressive movements. So with a black body in the background and white arms create to audience image of nightmare, the unaccomplished mission and still missing bones of soldiers who were killed in "hostile land".

We also found a beautiful costumes in a play "Waiting for Godot" director Fadil Hysaj , costume design -Maksut Vezgishi, in 24 February 1996.The play won the Special Jury Prize in a known International Festival. A known Albanian actor Luan Jaha performed Estragon character and Shkumbin Istrefi another known Albanian actor performed Vladimir character. They both had a long coat, sometimes in one of them was not seen panties of long coat so he looked funny and lazy person who loose beginning and hope. This game of coats and panties, dressing up and sheds clothes create to audience some significant artistic details and interactive form: coating-actor. Two white clothes of Son and Daughter are a significant contrast in dark background, without hope, violent and errant characters, who were and Vladimir, Estragon, Pozzo ( known Albanian actor Luan Daka) and Lucky( Skender Myftari actor) .

Costume designer Iliriana Loxha creates costumes to known play "Noble Bourgeoisie" Molier (French author (, in 1993). Clothes in this play were belonged in French classicism period and they aimed purity, elegance, cuttings, brilliance and freely function to actor on stage. Styling and using some modern elements into symbol language in suits were seen especially in the mid-80s. However costume to character looks expressive, paradoxal, luxury, primitive or extravagant they always express and show to audience meaning of the text.

Descriptive terms of character costumes, historical and social appear in 50-70 years in Albanian play and drama such as : "Halil and Hajria”, " Mayor" , "Nora from Kelemendi", “ Emira”, "Nita” , "Erveheja” , "Hotel Kashta" ,"Why sacrifice oath sallam ", "Death comes from such eyes", "Përkolgjinajt" and other foreign dramas : "Auditor", " Noble bourgeoisie", "Doll house”, "Makbeth", "Miserliness","Tartuff”, " Ah Xho ", "Waiting for Godot", " Konfiteor" , "Process ", "Father", etc. Costume design in those plays were with beautiful artistic and theatrical informations, all of these were showed character's curriculum vitae to audience ,where time and area were in one image. Also social and economic status of characters was appeared through costume design of them with beautiful actions of actors , racial, professional, ethnic and national affiliation then up to character mood.

Costume design which was presented in trilogy "Shore of sadness" Teki Dervishi, aimed distinct contrast on time and a journey of mythical allegorical and real hero. Konstandin Player to his country and Suka (character) , who has his mother and she was waiting for him to come with his sister Doruntina ( she was married far away). Clothing in this play was contrast with time and others- contrast with beauty and ugly, white and black , "Arbanon and non Arbanon".

Even though in costumes were used historical and ethnographical elements after 80 s have seen some modern styling. In some classic plays such as: "Tartuffe"," Uncle Vanja ", " Noble bourgeoisie", " George Dandin”, "Intrigue of love", " Auditor ", " Makbeth “, " King Lear", " Hamlet", " Richardi III ", "Ladies with Kamilije ", “ The bloody wedding", The man who saw a death ", " Antigona ", "King Edip ", "Oresteia ", " Braggart soldier" and so on. According historical data it is also aimed that costume design tried to be similar with our period.

Costumography followed modern and postmodern poetry theater in 80-90s, costume model for character had 
historical concept making transition or passing challenging of time. This poetry theater with costumes ideas has shown and featured current time. Through costume design also were practiced using of some modern forms, methods, school of art, theatre natural styles or mythological concepts during the two decades of 1980-1990. ${ }^{2}$.

Styles, developments and modern poetry were used in costume design for many theatre plays such as "Bald singer", “Waiting for Godot”, “ Lecture”, "Immigrants", “ Three colours farewell", "Trojan Horse”, “Idiot”, “ Nastasia Filipovna ", "Gof”, "Sfinga alive” , " Shore of sadness", “ Moon paper”, “ Prince of shadows” , "Illyrian plot", " Public dinners," "Where is the people", etc.

\section{ConCLUSION}

Descriptive terms of character costumes, historical and social appear in 50-70 years in Albanian play and drama such as : "Halil and Hajria”, " Mayor" , " Nora from Kelemendi", “ Emira”, "Nita” , "Erveheja” , "Hotel Kashta” , "Why sacrifice oath sallam ", " Death comes from such eyes", " Përkolgjinajt" and other foreign dramas : "Auditor", " Noble bourgeoisie", "Doll house ", "Makbeth" , "Miserliness","Tartuff", " Ah Xho ", "Waiting for Godot" , "Konfiteor" , " Process ", "Father", etc. Costume design in those plays were with beautiful artistic and theatrical informations, all of these were showed character`s curriculum vitae to audience ,where time and area were in one image. Also social and economic status of characters was appeared through costume design of them with beautiful actions of actors , racial, professional, ethnic and national affiliation then up to character mood.

\section{REFERENCES}

[1] Roland Barthes, Historie et socialogie du vetement (Ouvres complete), edit. Seuil, Paris, 2002, pages. 241-143.

[2] Papagjoni, Josif. Encyclopedia - Albanian Theatre and Filmmaking, Toena 2009, f.

[3] Papagjoni, Josif. Encyclopedia - Albanian Theatre and Filmmaking, Toena 2009, f.

[4] Papagjoni, Josif. Encyclopedia - Albanian Theatre and Filmmaking, Toena 2009, f.

[5] Papagjoni, Josif. Encyclopedia -Albanian Theatre and Filmmaking, Toena, 2009, f.

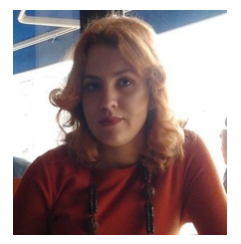

\section{AUTHOR's Biography}

Agnesa, Albanological Studies Center - Department of Art - Doctoral Section - History of Art, Tirana, Albania PHD, 2015, Teaching at Faculty of Arts, University of Prishtina, Kosovo.

Citation: Agnesa Muharremi, "Costume Design in Albanian Theatre in Kosovo", American Research Journal of Humanities and Social Sciences, Volume 2, 2016; pp:1-5

Copyright (C) 2016 Agnesa Muharremi. This is an open access article distributed under the Creative Commons Attribution License, which permits unrestricted use, distribution, and reproduction in any medium, provided the original work is properly cited. 